\title{
Kebijakan Penetapan Biaya Penyelenggaraan Ibadah Haji di Indonesia
}

\author{
Isabella $^{1)}$, Firdaus Komar ${ }^{2)}$ \\ ${ }^{1)}$ Program Studi Ilmu Pemerintahan, Universitas Indo Global Mandiri Palembang \\ ${ }^{2)}$ Jurusan Komunikasi, STISPOL Candradimuka Palembang \\ 1) Jl. Jend. Sudirman No. 629 KM. 4 Palembang Kode Pos 30129 \\ 2) Jl. Swadaya Sekip Ujung No.20 Ilir II, Ilir Timur I, Talang Aman, Kec. Kemuning, Palembang, 30127 \\ Email : isabella@uigm.ac.id ${ }^{1)}$, firdauskomar71@ gmail.com ${ }^{2}$
}

\begin{abstract}
Every year the interest of the Indonesian people to hajj continues to increase. In 2019 the number of Indonesian hajj will increase to 229,613 pilgrims. For this reason, appropriate policies are needed in making decisions in determining the amount of Hajj Operational Cost (BPIH) from Indonesia to Saudi Arabia. The study in this paper is a literature study of Political Economy. Political Economy is a theory or study of the role of public policy in influencing economic and social welfare in political relations (Merriam, 2018). According to Investopedia Political Economy is the study of production and trade, and its relation with costums, government and law. But in determining the amount of BPIH also influenced by many factors, such as world oil prices and the exchange rate of the rupiah. In relation to the determination of $\mathrm{BPIH}$, this is inseparable from fiscal policy. Fiscal policy is a government instrument to influence the economy in the context of realizing national development, which is elaborated through the management of the National Budget (Republic of Indonesia, 2015). Fiscal policy is an economic policy carried out by the government in order to manage and direct economic conditions in a better or desired way by changing or updating government revenues and expenditures, one of the highlights of this fiscal policy is controlling government expenditure and revenue or country
\end{abstract}

Keywords : Policy, hajj, fiscal

\begin{abstract}
Abstrak
Setiap tahun minat masyarakat Indonesia untuk menunaikan ibadah haji terus mengalami peningkatan. Tahun 2019 jumlah jamaah haji Indonesia meningkat menjadi 229.613 jamaah. Untuk itu diperlukan kebijakan-kebijakan yang tepat dalam pengambilan keputusan dalam menetapkan besaran Biaya Penyelenggaraan Ibadah Haji (BPIH) dari Indonesia ke Arab Saudi. Kajian dalam tulisan ini merupakan studi literatur Ekonomi Politik. Ekonomi Politik adalah teori atau studi tentang peran kebijakan publik dalam mempengaruhi kesejahteraan ekonomi dan sosial dalam kaitan politik (Merriam, 2018). Menurut Investopedia, Ekonomi Politik adalah studi tentang produksi dan perdagangan dan hubungannya dengan adat, pemerintah dan hukum. Dalam penentuan BPIH telah diatur sesuai dengan mekanisme yang ada di Indonesia. Namun dalam menetukan besaran BPIH juga dipengaruhi oleh banyak faktor, seperti harga minyak dunia dan kurs nilai tukar rupiah. Kebijakan fiskal merupakan instrumen Pemerintah untuk mempengaruhi perekonomian dalam rangka mewujudkan pembangunan nasional, yang dijabarkan melalui pengelolaan APBN (Republik Indonesia, 2015). Kebijakan fiskal adalah kebijakan ekonomi yang dilakukan oleh pihak pemerintah guna mengelola dan mengarahkan kondisi perekonomian ke arah yang lebih baik atau yang diinginkan dengan cara mengubah atau memperbarui penerimaan dan pengeluaran pemerintah, saalah satu hal yang ditonjolkan dari kebijakan fiskal ini adalah pengendalian pengeluaran dan penerimaan pemerintah atau Negara.
\end{abstract}

Kata kunci : Kebijakan, haji, fiskal 


\section{Pendahuluan}

Indonesia merupakan negara yang penduduknya mayoritas beragama islam dan terbanyak di dunia. Dalam menjalankan ajaran agamanya terdapat kewajiban untuk melaksanakan ibadah haji ke Makkah di Arab Saudi. Aktivitas ibadah haji ini tentunya memerlukan biaya yang besar mengingat jarak antara negara Arab Saudi dengan Indonesia cukup jauh, sekitar $7.898 \mathrm{~km}$ atau sekitar sembilan jam perjalanan dengan menggunakan pesawat udara.

Setiap tahun minat masyarakat Indonesia untuk menunaikan ibadah haji terus mengalami peningkatan. Jumlah minat masyarakat untuk menunaikan ibadah haji dapat dilihat pada gambar berikut:

Grafik Jumlah Jamaah Haji Indonesia tahun 2017-2019

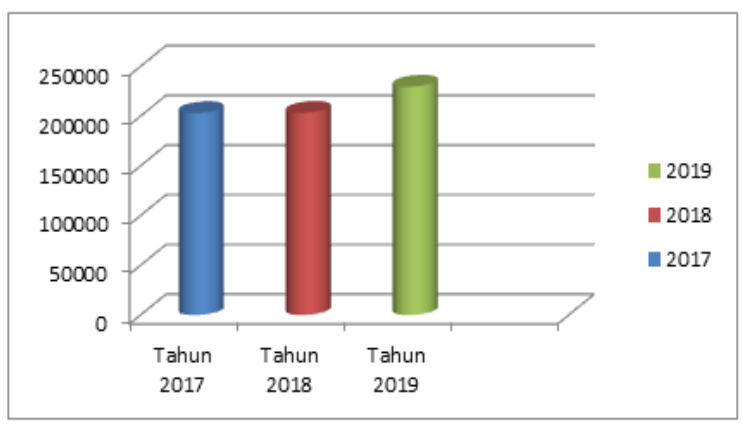

Sumber: Kemenag (data diolah)

Gambar 1. Grafik Jumlah Jamaah Haji Indonesia Tahun 2017-2019

Berdasarkan tabel di atas dapat dilihat bahwa jumlah biaya jamaah haji bagi Indonesia pada tahun 2017 sebanyak 203.070 jamaah. Selanjutnya pada tahun 2018 meningkat menjadi 203.350 jamaah. Sedangkan pada tahun 2019 jumlah jamaah haji Indonesia meningkat lagi menjadi 229.613 jamaah. Hal ini menunjukan bahwa animo masyarakat untuk menunaikan ibadah haji terus meningkat meskipun jarak tempuhnya dari Indonesia cukup jauh.

Peningkatan jumlah jamaah haji ini tentunya membuat pemerintah harus bekerja keras untuk memberikan pelayanan terbaik kepada masyarakat. Untuk itu diperlukan kebijakan-kebijakan yang tepat dalam pengambilan keputusan dalam menetapkan besaran Biaya Penyelenggaraan Ibadah Haji (BPIH) dari Indonesia ke Arab Saudi. Kementerian Agama menyebutkan kuota haji Indonesia pada 2019 sama seperti pada 2018, yakni sebesar 221 ribu. Angka itu terdiri atas 204 ribu haji reguler dan 17 ribu haji khusus.

Selanjutnya, jika berbicara masalah penyelenggaraan haji menurut Muhammad Arif Budiman (2015), dalam perspektif Sosiologis haji mempertemukan umat Islam dari seluruh penjuru dunia dalam satu even akbar tahunan di kota Mekkah dan daerah-daerah sekitarnya. Lebih dari tiga juta muslim berkumpul dengan mengenakan pakaian yang sama, mengumandangkan pujian kebesaran untuk Sang Penguasa Semesta. Selain itu, perjalanan haji juga dipersepsikan oleh banyak kalangan sebagai sarana yang dapat meningkatkan status sosial. Orang yang telah melakukan ibadah haji umumnya mendapatkan status dan posisi terhormat di tengah-tengah masyarakat.

Sementara itu, penyelenggaraan haji yang melibatkan jutaan orang di satu titik pada saat yang bersamaan tentunya menjadi rangkaian aktivitas yang amat spektakul ditinjau dari perspektif ekonomi. Beragam sektor usaha mulai dari transportasi, perhotelan, perdagangan, restoran, tekstil, komunikasi, hingga beraneka jasa mengalami lonjakan permintaan fantastis. Perspektif lainnya yang tak kala penting berperan dalam penyelenggaraan haji ini adalah perspektif politik. Dalam menentukan BPIH bagi masyarakat Indonesia pemerintah tidak dapat bekerja sendiri. Dalam hal ini pemerintah harus berkoordinasi dengan pihak-pihak terkait seperti DPR, swasta, dalam hal ini seperti biro perjalanan haji dan umrah/travel agen departemen kesehatan dan departemen perhubungan dan pihak-pihak lainnya. Untuk itulah perlu pembahansan lebih lanjut mengenai BPIH di Indonesia ini.

Kajian dalam makalah ini tidak terlepas dari kaitannya dengan Ekonomi Politik. Ekonomi Politik adalah teori atau studi tentang peran kebijakan publik dalam mempengaruhi kesejahteraan ekonomi dan sosial dalam kaitan politik (Merriam, 2018). Menurut Investopedia, Ekonomi Politik adalah studi tentang produksi dan perdagangan dan hubungannya dengan adat, pemerintah dan hukum. Ilmu ini merupakan studi dan penggunaan teori dan metode ekonomi yang mempengaruhi sistem sosial dan ekonomi yang berbeda dan berkembang, seperti kapitalisme, sosialisme; dll dan juga menganalisis bagaimana kebijakan publik dibuat dan diimplementasikan.

Karena berbagai individu dan kelompok memiliki kepentingan yang berbeda dalam suatu negara atau ekonomi yang berkembang, maka Ekonomi Politik dianggap sebagai suatu disiplin ilmu yang kompleks, mencakup beragam kepentingan yang berpotensi terjadinya persaingan.

Sebagai suatu disiplin ilmu, ekonomi politik penuh dengan filsafat moral, yang pada abad ke-18, digunakan untuk mengeksplorasi administrasi kekayaan negara, saat itu dikaitkan dengan pengertian pemerintahan ("politik" = pemerintahan dan 'ekonomi' yang berarti manajemen rumah tangga dalam bahasa Yunani).

Pada akhir abad ke-19, istilah "ekonomi" diperkenalkan dengan istilah "ekonomi politik" dengan munculnya pemodelan matematika dari penerbitan buku teks yang berpengaruh oleh Alfred Marshall pada tahun 1890 dan kemudian Ekonomi Politik mulai lebih dikenal pada 1920. Saat ini, ekonomi politik merupakan pendekatan yang berbeda dan tidak digunakan sebagai sinonim untuk ekonomi, serta dapat merujuk pada halhal yang sangat berbeda.

Dalam kaitannya dengan kajian kebijakan penetapan biaya perjalanan haji, tentunya tidak terlepas dari konteks kebijakan publik. Istilah kebijakan publik berasal dari dua kata, yaitu" kebijakan" dan "publik". Kemudian istilah ini disepadankan dengan kata dalam 
bahasa Inggris "policy" yang dibedakan dari kata "wisdom" yang berarti kebijaksanaan atau kearifan. Kebijakan publik berasal dari kata " public policy" (Komar, 2012:10). Menurut Wayne Parsons (2005:XI) berpendapat kebijakan publik menitik beratkan pada apa yang oleh Dewey (1972) katakan sebagai "publik dan problem-problemnya".

Berdasarkan pendapat Wayne Parsons ini dapat disimpulkan semua permasalahan publik adalah masuk dalam kajian kebijakan publik. Untuk itu dalam mengatasi masalah publik diperlukan kebijakan pemerintah sehingga dapat merumuskan langkahlangkah pemecahan masalah publik.

Menurut Irfan Islamy (1994) Kebijakan Publik merupakan serangkaian tindakan yang dipilih dan dialokasikan secara sah oleh pemerintah atau negara kepada seluruh anggota masyarakat yang mempunyai tujuan tertentu demi kepentingan publik.

Menurut Thomas R. Dye (2008:1) mendefinisikan kebijakan publik adalah "whatever governments chooes to do or not to do" (kebijakan publik adalah apapun yang dipilih pemerintah untuk dilakukan atau tidak dilakukan). Kebijakan publik menurut R. Dye tersebut memberikan penekanan bahwa apapun kegiatan pemerintah baik secara eksplisit maupun implisit sudah merupakan suatu kebijakan, termasuk diamnya pemerintah terhadap permasalahan publik merupakan suatu kebijakan yang telah diambil oleh pemerintah.

Selanjutnya menurut Andy Al Fatih (2010:2) kebijakan publik adalah setiap keputusan atau tindakan yang dibuat secara sengaja dan sah oleh pemerintah yang bertujuan untuk melindungi kepentingan publik, mengatasi masalah publik, memberdaya publik, dan menciptakan kesejahteraan publik

Untuk mengkaji kebijakan penetapan biaya penyelenggaraan ibadah haji khususnya di Indonesia, maka dasar-dasar penelitian terdahulu akan memperkaya pemahaman dalam melakukan perbandingan. Penelitian terdahulu yang dipakai adalah sebagai berikut:

1. Arie Haura (2010) dalam penelitiannya yang berjudul "Pengelolaan Dana Haji Pada Sukuk Dana Haji Indonesia (SDHI)" menjelaskan bahwa dana SDHI digunakan untuk pembiayaan secara umum (general financing), bukan untuk membiayai proyek (project financing). Pengelolaan dana haji pada Sukuk Dana Haji Indonesia adalah untuk pembiayaan defisit anggaran mengingat penggunaannya adalah tergolong untuk pembiayaan secara umum. Secara umum, Sukuk Dana Haji Indonesia menimbulkan dampak negatif dari sisi sektor keuangan, yaitu:

a. Mengurangi Dana Pihak Ketiga (DPK) pada bank syariah.

b. Menimbulkan keragu-raguan dari segi pengelolaannya, mengingat Sukuk Dana Haji Indonesia tersebut ditempatkan untuk general financing jadi terdapat kekhawatiran tercampur dengan dana selain sukuk.
2. Nashuddin (2011) dalam penelitiannya yang berjudul "Sistem Pelayanan Haji Pada Kanwil Kementerian Agama Provinsi Nusa Tenggara Barat" menjelaskan bahwa sistem pelayanan haji pada Kementerian Agama Provinsi Nusa Tenggara Barat dilakukan melalui tahapan-tahapan pemberian informasi, pendaftaran, pelayanan kesehatan, bimbingan manasik, akomodasi dan konsumsi, serta transportasi. Tahapan pelayanan tersebut di atas mengacu pada sembilan prinsip pelayanan prima. Prinsip- prinsip pelayanan prima yang dijadikan tolok ukur pelayanan memuaskan bagi jemaah haji disempurnakan dengan empat prinsip terpadu, adaptif responsif dan wawasan yang merupakan temuan penelitian. Dalam pelayanan manasik, prinsip efisiensi belum tercapai. Demikian juga pada aspek transportasi, prinsip kesederhanaan, kejelasan dan kepastian serta ketepatan waktu belum tercapai.

\section{Pembahasan}

Sebagaimana tertuang dalam Undang-Undang Nomor 8 Tahun 2019 tentang Penyelenggaraan Ibadah Haji dan Umrah pasal 1 yang dimaksud dengan Ibadah Haji adalah rukun Islam kelima bagi orang Islam yang mampu untuk melaksanakan serangkaian ibadah tertentu di Baitullah, masyair, serta tempat, waktu, dan syarat tertentu.

Penyelenggaraan ibadah haji di Indonesia mengalami perkembangan dari masa ke masa. Pada masa kolonial, penyelengggaraan haji dilaksanakan oleh perusahaan swasta tanpa keterlibatan pemerintah. Tiga perusahaan swasta terbesar saat itu adalah Kongsi Tiga, Herklots, dan Alsegoff \& Co.. Setelah kemerdekaan, berdiri Yayasan Perjalanan Haji Indonesa (PHI) pada tahun 1950 yang mengelola penyelenggaraan haji di bawah pimpinan tokoh-tokoh umat Islam. Yayasan ini mendapatkan dukungan penuh dari pemerintah dan ditetapkan sebagga satu-satunya lembaga yang mengurusi haji di tanah air. Sejak tahun 1969, dibawah pemerintah Orde Baru, pengelolaan haji berubah sepenuhnya di bawah kendali pemerintah (Ichwan, 2008).

Meskipun demikian, masyarakat diberi ruang secara terbatas untuk terlibat dalam penyelenggaraan haji melalui program ONH Plus atau non-BPIH. Indonesia selama ini tercatat sebagai negara yang mengirimkan delegasi haji terbesar di antara semua negara di dunia.

Kendati faktor keagamaan dan ekonomi memegang peran penting di balik keputusan seseorang untuk naik haji, seperti didiskusikan di atas, ternyata faktor sosial dan budaya juga turut berperan mendorong seseorang untuk berangkat ke Tanah Suci (Sulthoni, Muhlisin, \& Mutho'in, 2012). Bahkan lebih jauh lagi, Ichwan (2008) yang mengkaji kebijakan pemerintah dalam pengelolaan haji sampai pada kesimpulan bahwa kompleksitas dan kerumitan pengelolaan ibadah haji bukanlah karena faktor keagamaannya, melainkan lebih kental karena faktor ekonomis dan politisnya.

Dalam penentuan BPIH telah diatur sesuai dengan mekanisme yang ada di Indonesia. Namun dalam 
menetukan besaran BPIH juga dipengaruhi oleh banyak faktor, seperti harga minyak dunia dan kurs nilai tukar rupiah. Penetapan BPIH berdasarkan Undang-Undang Nomor 8 Tahun 2019 tentang Penyelenggaraan haji dan Umroh, pada Pasal 48 (1) Besaran BPIH ditetapkan oleh Presiden paling lama 30 (tiga puluh) Hari setelah usulan BPIH mendapatkan persetujuan dari DPR RI

Pasal (2) Besaran BPIH sebagaimana dimaksud pada ayat (1) yang bersumber dari Bipih, Nilai Manfaat, Dana Efisiensi, dan/atau sumber lain yang sah berdasarkan ketentuan peraturan perundangundangan ditetapkan oleh Presiden atas usul Menteri setelah mendapat persetujuan dari DPR RI.

Biaya untuk melaksanakan haji di Indonesia dikenal dengan nama Biaya Penyelenggaraan Ibadah Haji (BPIH). Sebelum dikeluarkannya UU No.17/1999 tentang Penyelenggaraan Haji, biaya ini disebut dengan Ongkos Naik Haji (ONH). Penetapan BPIH dilakukan oleh Presiden atas usul Menteri Agama setelah mendapat persetujuan DPR RI. Dengan kata lain, penyusunan BPIH dilakukan secara konsultatif antara Pemerintah dengan DPR RI. Selanjutnya, besaran BPIH yang sudah disepakatii dituangkan dalam Keputusan Presiden (Keppres).

Dalam kaitannya dengan penentuan BPIH ini tidak terlepas dari kebijakan fiskal. Tujuan utama dari sistem ekonomi nasional untuk mencapai kesejahteraan baik material maupun non material (Prasetyia, 2011). Kebijakan fiskal merupakan instrumen Pemerintah untuk mempengaruhi perekonomian dalam rangka mewujudkan pembangunan nasional, yang dijabarkan melalui pengelolaan APBN (Republik Indonesia, 2015). Kebijakan fiskal adalah kebijakan ekonomi yang dilakukan oleh pihak pemerintah guna mengelola dan mengarahkan kondisi perekonomian ke arah yang lebih baik atau yang diinginkan dengan cara mengubah atau memperbarui penerimaan dan pengeluaran pemerintah, saalah satu hal yang ditonjolkan dari kebijakan fiskal ini adalah pengendalian pengeluaran dan penerimaan pemerintah atau negara.

Jika dilihat besaran BPIH tahun 2017-2019 tidak terjadi kenaikan dengan jumlah besaran Rp 35.235.602 atau sekitar US\$2.632. Komponen-komponen yang menjadi tolok ukur BPIH, antara lain dalam bentuk US\$ untuk biaya penerbangan Indonesia-Arab Saudi (pulang pergi/PP) dan biaya operasional di Arab Saudi. Sedangkan biaya tambahan dalam bentuk rupiah adalah untuk operasional dalam negeri. Secara ringkas masingmasing komponen perhitungan BPIH dapat dijelaskan sebagai berikut:

a. Biaya penerbangan adalah biaya yang harus dibayar oleh pemerintah kepada pihak penerbangan yang mengangkut jamaah haji yang dilakukan secara charter. Biaya angkutan udara merupakan komponen terbesar dalam susunan BPIH yaitu antara 40-48\%.

b. Biaya Operasional di Arab Saudi merupakan biaya yang dipergunakan untuk penyelenggaraan operasional di Arab Saudi dan biaya yang harus dibayarkan oleh Pemerintah Indonesia kepada penyedia pelayanan haji di Arab Saudi. c. Biaya operasional dalam negeri merupakan biaya yang dipergunakan untuk penyelenggaraan operasional haji di Indonesia yang terdiri dari biaya operasional Pusat, biaya operasional di embarkasi, biaya operasional di daerah, airport tax dan biaya jasa administrasi bank (KPPU, 2008).

Di samping membayar besarnya BPIH yang telah ditetapkan, jamaah haji masih harus menanggung biaya lain yang tidak termasuk dalam komponen BPIH, yaitu biaya pemeriksaan kesehatan, perjalanan dari daerah asal ke asrama embarkasi dan sebaliknya, biaya ziarah di Arab Saudi dan biaya dam (kewajiban menyembelih hewan ternak sebagai kompensasi atas ditinggalkannya sebagian kewajiban haji).

Mengingat beban penerbangan merupakan komponen dari BPIH (terbesar $(47,53 \%$ dari BPIH), maka perubahan pada komponen ini dapat dipastikan mempengaruhi besaran BPIH. Kementerian Agama selaku regulator, asosiasi penyelenggara haji umrah, maupun operator penerbangan mengaku adanya hubungan antara harga bahan bakar dengan BPIH. Kenaikan minyak secara otomatis mendorong peningkatan besaran BPIH. Oleh karenanya BPIH masing-masing embarkasi ditetapkan berbeda-beda pula.

Berikut ini daftar besaran BPIH 1440H/2019M jamaah haji reguler per embarkasi:

$\begin{array}{clll}1 & \text { Embarkasi } & \text { Aceh } & \text { Rp 30.881.010; } \\ 2 & \text { Embarkasi } & \text { Medan } & \text { Rp 31.730.375; } \\ 3 & \text { Embarkasi } & \text { Batam } & \text { Rp 32.306.450; } \\ 4 & \text { Embarkasi } & \text { Padang } & \text { Rp 32.918.065; } \\ 5 & \text { Embarkasi } & \text { Palembang } & \text { Rp 33.429.575; } \\ 6 & \text { Embarkasi } & \text { Jakarta (Pondok } & \text { Rp 34.987.280; } \\ & & \text { Gede) } & \\ 7 & \text { Embarkasi } & \text { Jakarta (Bekasi) } & \text { Rp 34.987.280; } \\ 8 & \text { Embarkasi } & \text { Solo } & \text { Rp 36.429.275; } \\ 9 & \text { Embarkasi } & \text { Surabaya } & \text { Rp 36.586.945; } \\ 10 & \text { Embarkasi } & \text { Banjarmasin } & \text { Rp 37.885.084; } \\ 11 & \text { Embarkasi } & \text { Balikpapan } & \text { Rp 38.259.345; } \\ 12 & \text { Embarkasi } & \text { Lombok } & \text { Rp 38.454.405; } \\ 13 & \text { Embarkasi } & \text { Makassar } & \text { Rp 39.207.741; }\end{array}$

Berikut ini daftar besaran BPIH 1440H/2019M TPHD per embarkasi:

$\begin{array}{llll}1 & \text { Embarkasi } & \text { Aceh } & \text { Rp 66.645.504; } \\ 2 & \text { Embarkasi } & \text { Medan } & \text { Rp 67.363.504; } \\ 3 & \text { Embarkasi } & \text { Batam } & \text { Rp 67.905.304; } \\ 4 & \text { Embarkasi } & \text { Padang } & \text { Rp 68.363.504; } \\ 5 & \text { Embarkasi } & \text { Palembang } & \text { Rp 68.566.804; }\end{array}$

Hal ini banyak faktor yang mempengaruhi, selain jarak tempuh, juga faktor-faktor ekonomi politik dan sosial lainnya. Secara ekonomi pengelola perjalanan ibadah haji tentunya menginginkan keuntungan yang sesuai dengan kondisi sekarang. Di sisi lain pemerintah pun mempunyai beban dalam memberangkatkan pejabatpejabat negara, tim kementerian agama, tim medis, media, biaya-biaya operasional dan pihak-pihak lainnya yang terkait pelayanan jamaah haji selama di Arab Saudi. Hal ini tentunya menggunakan dana-dana jamaah yang telah terkumpul sebelumnya.

Untuk itulah perlu pengelolaan dan pengawasan yang tepat terhadap penggunaan dana BPIH, karena 
menyangkut kepentingan orang banyak dan uang rakyat. Meskipun ada kepentingan-kepentingan politik dan ekonomi serta sosial, aturan ataupun regulasi yang berkenaan dengan penyelenggaraan haji harus tetap di tegakkan. Dengan demikian memperkecil peluang untuk terjadinya penyalahgunaan dana BPIH.

Menurut informasi Kementerian Agama pada akhir tahun 2016, perkiraan jumlah setoran dana haji ke Kementerian Agama mencapai Rp76 triliun dan akan menembus angka Rp100 triliun. Jumlah yang tidak sedikit ini menimbulkan berbagai dampak. Nilai yang triliunan ini tidak hanya menyimpan investasi ekonomis yang sangat tinggi, tetapi juga menimbulkan dampak politis yang tinggi pula. Untuk menjaga agar dana haji dapat dikelola dengan baik, UU Nomor 34 Tahun 2014 tentang Pengelolaan Keuangan Haji, mengamanahkan untuk membuat suatu badan khusus pengelolan keuangan haji (Badan Pengelola Keuangan Haji atau $\mathrm{BPKH})$ yang bertugas mengelola penerimaan, pengembangan, pengeluaran, dan pertanggungjawaban keuangan haji.

Beberapa waktu yang lalu di media mucul suatu polemik mengenai boleh tidaknya dana haji diinvestasikan ke dalam pembiayaan infrastruktur. Sebetulnya menurut UU di atas, BPKH hanya mempunyai batasan investasi pada instrumen syariah yang aman dan bermanfaat. Jadi tidak ada batasan pada sektor apa dana tersebut akan diinvestasikan. Namun yang lebih ditekankan adalah pada sisi keamanan, kemanfaatan dan kehatihatiannya. Namun hendaknya jangan sampai dana tersebut diinvestasikan pada sektor yang kurang aman hanya karena mengejar imbal hasil yang cukup tinggi. Prioritas kepentingan jamaah untuk memperoleh manfaat tambahan atas dananya yang tersimpan sekian lama harus memperoleh diperhatikan, bukan hanya sekedar mengejar keuntingan berinvestasi semata.

Akhir-akhir ini Kementerian Keuangan tengah menggalakkan pembiayaan infrastruktur melalui penerbitan Sukuk Negara berbasis pembiayaan proyek (Project Based Sukuk atau PBS). Salah satu kementerian yang cukup banyak memperoleh pembiayaan dari Sukuk PBS adalah Kementerian Agama, terutama untuk pembangunan gedung baru (gedung UIN atau IAIN dan gedung KUA yang jumlahnya ratusan). Sehingga masyarakat menghubungkan praktik penempatan dana haji pada SDHI selama ini dengan pembiayaan proyekproyek Kementerian Agama.

Penentuan penggunaan proceeds adalah kewenangan Kementerian Keuangan sebagaimana tersebut dalam UU Nomor 19 Tahun 2008 tentang SBSN. Dalam aturan ini dijelaskan bahwa pemanfaatan dana hasil penerbitan SBSN (proceeds) dapat digunakan untuk pembiayaan umum APBN dan pembangunan proyek-proyek Pemerintah. Jadi apabila dana haji ditempatkan dalam SBSN, maka penentuan penggunaannya ada pada Kementerian Keuangan dan tidak dapat diarahkan langsung ke proyek infrastruktur Kementerian Agama. Apabila Kementerian Agama menginginkan proyek infrastrukturnya dibiayai dengan penerbitan SBSN, maka pengusulannya harus sesuai dengan mekanisme APBN yang telah ada termasuk harus melalui Bappenas.

Penempatan dana haji ke dalam SBSN sebenarnya lebih didasarkan pada keamanan dalam berinvestasi dan keuntungan berupa imbalan dari SBSN. Selama ini dengan menggunakan SDHI yang bersifat private placement (penempatan sendiri) memberikan keuntungan bagi Kementerian Agama dalam menentukan tenor SDHI yang disesuaikan dengan rencana pemanfaatan dana tersebut. Namun SDHI merupakan instrumen non-tradeable (tidak dapat diperdagangkan) sehingga tidak bisa di-redeem setiap saat. Sebenarnya Kementerian Agama dapat pula menempatkan dana haji ke Sukuk Negara seri PBS yang bersifat tradeable (dapat diperdagangkan). Dengan memegang instrumen yang tradeable maka kelak pengelola keuangan haji dapat lebih leluasa dalam mengatur likuiditasnya karena bisa di-redeem setiap saat melalui pasar sekunder.

Dana haji yang jumlahnya sangat besar tersebut memang sangat potensial untuk dimanfaatkan dalam mendukung pembangunan infrastruktur melalui mekanisme penempatan dana yang telah ada. Dana haji sebenarnya menyimpan multiplier effects yang sangat banyak. Disatu sisi, ketika dana tersebut ditempatkan dalam Sukuk PBS maka akan membantu pembangunan infrastruktur yang mampu menggulirkan pertumbuhan ekonomi dengan banyaknya lapangan kerja baru yang dibuka dan masyarakat yang dibuat sejahtera (Eri Haryanto, 2017

\section{Kesimpulan}

Pergerakan nilai BPIH di Indonesia dari tahun ke tahun bersifat dinamis karena dipengaruhi banyak faktor, seperti ekonomi, politik, dan sosial Namun mengingat besaran BPIH ditetapkan jauh sebelum pelaksanaan ibadah haji dan bersifat final, maka perkembangan yang terkait perubahan nilai tukar dan harga minyak, penetapannya memberikan pengaruh terhadap BPIH.

Hal lain yang perlu menjadi perhatian semua pihak terkait penentuan BPIH di Indonesia, adalah keputusankeputusan yang dibuat oleh pemerintah dalam hal ini presiden dibantu kementerian Agama dalam menentukan BPIH tidak hanya berpedoman kepada keputusankeputusn politik semata. Namun harus tetap mempertimbangkan kondisi perekonomian masyarakat Indonesia secara keseluruhan. Terlebih lagi keputusan politik yang dipengaruhi oleh persetujuan DPR RI. Anggota DPR yang memegang peranan penting dalam penentuan BPIH pun harus bijak mempertimbangkan segala sesuatu akibat dari keputusan yang akan dikeluarkan. Mengingat kepentingan masyarakat di atas segalanya.

Pelayanan jamaah haji di tanah suci pun tidak terlepas dari perhatian masyarakat, mengingat para jamaah telah membayar mahal BPIH. Secara kualitas pelayanan pun harus terus ditingkatkan guna kelancaran ibadah para jamaah selama di tanah suci. 
Peran pihak swasta dalam pengelolaan dan pelayanan jamaah haji, menjadi penting ketika segala pelayanan mulai dari pemberangkatan di Indonesia hingga sampai ditanah suci dan kembali lagi ke Indonesia. Terutama pada sektor-sektor yang tidak dapat dikelola oleh pemerintah secara mandiri, seperti penyediaan transportasi, konsumsi, pengadaan perlengkapan haji, hingga publikasi kegiatan haji.

Untuk itu perlu dukungan semua pihak agar pengelolaan BPIH dapat secara maksimal termanfaatkan dengan baik guna menunjang kelancaran ibadah para jamaah haji Indonesia.

\section{Daftar Pustaka}

Budiman, Arief. 2016. Analisis Faktor yang Mempengaruhi Penyelenggaraan Biaya Haji di Indonesia. Jurnal Hukum Islam, Vol. 14, No. 1, Juni 2016

Handbook of Public Economics .VOL.3

Nainggolan, Poltak : Peran Kapital Dan Gagalnya Konsolidasi Demokratis Indonesia: Pendekatan Ekonomi-Politik Politica Vol. 7 No. 1 Mei 2016

Syamsir, Ahmad. Implementasi Kebijakan Penyelenggaraan Ibadah Haji Di Kota Bandung Tahun 2018. JISPO VOL. 9 No. 1 Edisi: JanuariJuni Tahun 2019.

https://www.cnnindonesia.com/nasional/2020013016103 2-20-470194/kemenag-dan-dpr-sepakat-ongkoshaji-2020-tetap-rp352-juta

https://www.researchgate.net/publication/275973371_A NALISIS_FAKTOR_YANG_MEMPENGARUHI _BIAYA_PENYELENGGARAAN_IBADAH_HA JI_DI_INDONESIA

https://news.detik.com/berita/d-4413836/dpr-menagsahkan-biaya-haji-tahun-2019-sebesar-rp-352-juta

https://ww.google.co.id/search?q=jumlah+jamaah+umra $\mathrm{h}+$ indonesia + dari + tahun $+\mathrm{ke}+$ tahun $\&$ safe $=$ strict $\& \mathrm{tb}$ $\mathrm{m}$

Undang-Undang Nomor 8 Tahun 2019 tentang Pengelenggaraan Ibadah Haji dan Umrah

http://jurnalius.ac.id/ojs/index.php/jurnalIUS/article/dow nload/161/137

https://news.detik.com/berita/d-4318454/ini-alasankemenag-tak-tambah-kuota-haji-2019

https://www.hidayatullah.com/berita/info-hajiumrah/read/2019/03/15/161384/keppres-bpih-2019terbit-ini-biaya-haji-per-embarkasi.html

https://wwwww.djppr.kemenkeu.go.id/uploads/files/Kaji an_Artikel_DJPPR/Investasi\%20Dana\%20Haji\%2 0pada\%20Sukuk\%20Infrastruktur.pdf

http://etheses.uinmalang.ac.id/2480/6/12521001_Bab_2. pdf

http://digilib.uinsuka.ac.id/20293/2/12380098_BAB

I_IV-atau-V_DAFTAR-PUSTAKA.pdf 